\title{
PENGARUH PENERAPAN PROJECT BASED LEARNING TERHADAP KEMAMPUAN BERPIKIR KREATIF CALON GURU MATEMATIKA DALAM MENGEMBANGKAN BAHAN AJAR MATEMATIKA
}

\author{
Nurma Izzati
Tadris Matematika, IAIN Syekh Nurjati Cirebon Jl. Perjuangan No.1 By Pass Sunyaragi Cirebon \\ izzah tiar@yahoo.com
}

\begin{abstract}
Penelitian ini bertujuan untuk menelaah pengaruh penerapan project based learning terhadap kemampuan berpikir kreatif calon guru matematika dalam mengembangkan bahan ajar matematika. Desain penelitian ini adalah one-shot case study. Populasi penelitian adalah seluruh mahasiswa Jurusan Tadris Matematika IAIN Syekh Nurjati Cirebon pada semester genap tahun akademik 2017/2018 dengan populasi terjangkau adalah seluruh mahasiswa jurusan Tadris Matematika IAIN Syekh Nurjati Cirebon yang mengambil mata kuliah pengembangan bahan ajar matematika pada semester genap tahun akademik 2017/2018 yakni sebanyak empat kelas yang berjumlah 138 orang mahasiswa. Dari populasi terjangkau dipilih satu kelas sampel dengan teknik cluster random sampling, yaitu seluruh mahasiswa kelas $C$ yang mengikuti mata kuliah pengembangan bahan ajar matematika sebanyak 33 orang mahasiswa. Teknik pengumpulan data menggunakan tes kemampuan berpikir kreatif dan angket respon mahasiswa terhadap penerapan project based learning. Hasil penelitian menunjukkan bahwa penerapan project based learning berpengaruh secara signifikan terhadap kemampuan berpikir kreatif calon guru matematika dalam mengembangkan bahan ajar matematika.
\end{abstract}

Keywords: berpikir kreatif, project based learning, bahan ajar, matematika

\section{PENDAHULUAN}

\section{Latar Belakang}

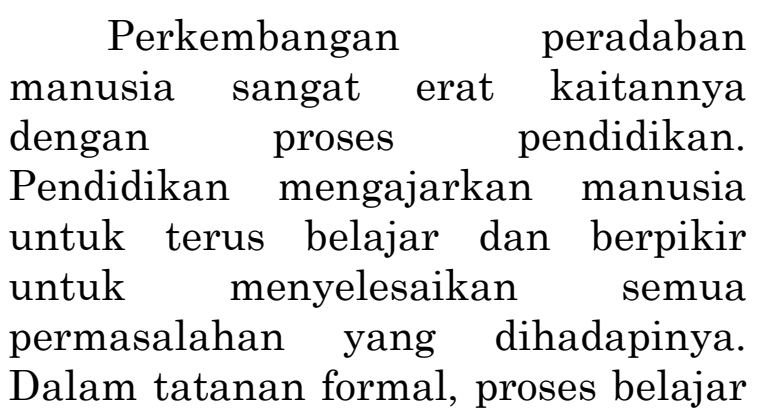

mengajar di sekolah meliputi banyak hal, mulai dari guru sebagai pendidik, siswa sebagai peserta didik, sampai saran dan prasarana pendukung proses belajar mengajar di sekolah termasuk bahan ajar yang digunakan. Proses belajar mengajar di sekolah akan berjalan dengan baik jika semua unsurnya memahami tugas dan perannya dengan baik. Guru sebagai pendidik salah satunya dituntut untuk mampu membuat dan 
mengembangkan bahan ajar yang akan diajarkan ke peserta didik nya dengan baik. Bahan ajar yang dibuat sendiri oleh guru akan lebih memudahkan guru untuk menyampaikan materi ajarnya.

Kreatifitas dalam membuat dan mengembangkan bahan ajar ini harus dimiliki oleh setiap guru, agar guru tersebut dapat menyajikan materi dengan baik kepada peserta didiknya. Apalagi jika materi yang akan diajarkan merupakan materi yang tidak mudah dimengerti peserta didik, seperti pelajaran matematika, maka bahan ajar yang diberikan haruslah dibuat dan dikembangkan sehingga peserta didik lebih mudah untuk memahaminya.

Sebagai calon guru matematika, mahasiswa jurusan tadris matematika harus mampu untuk membuat dan mengembangkan bahan ajar matematika dengan baik. Untuk mencapai tujuan tersebut salah satu mata kuliah yang diberikan adalah mata kuliah pengembangan bahan ajar matematika. Dalam mata kuliah ini mahasiswa diajarkan untuk berpikir kreatif dalam mengembangkan berbagai macam bahan ajar yang dapat digunakan dalam mengajarkan materi matematika dengan baik dan benar, sehingga materi matematika yang abstrak menjadi lebih mudah dipahami oleh peserta didik.

Salah satu upaya yang dilakukan agar kemampuan berpikir kreatif mahasiswa calon guru matematika dalam mengembangkan bahan ajar matematika adalah dengan memberikan berbagai strategi pembelajaran yang tepat. Salah satunya dengan menerapkan project based learning. Mahasiswa diberikan tugas proyek untuk mengembangkan berbagai macam bahan ajar matematika. Diharapkan mahasiswa dapat dengan kreatif menciptakan berbagai macam bahan ajar matematika yang dapat digunakan untuk membantu proses pembelajaran matematika menjadi lebih efektif dan menyenangkan.

Penerapan project based learning dalam penelitian ini mahasiswa secara berkelompok diminta membuat berbagai macam bahan ajar matematika yang sesuai dengan materi ajar untuk jenjang SMP dan SMA. Proses penyelesaian proyek dikerjakan mulai dari proses perencanaan, proses pembuatan, sampai mempresentasikan produk akhir di depan kelas.

Kemampuan berpikir kreatif mahasiswa dalam menyelesaikan semua proyek yang diberikan sangat diperlukan untuk menghasilkan bahan ajar matematika yang inovatif namun tetap memperhatikan konsepkonsep matematika dengan benar. Setiap kelompok diberi tugas/proyek yang sama, namun harus menghasilkan produk yang berbeda antar masing-masing kelompok, sehingga kemampuan berpikir kreatif mahasiswa dalam mengembangkan bahan ajar matematika benar-benar diasah.

Berdasarkan pemaparan di atas, maka diharapkan penerapan project based learning berpengaruh terhadap kemampuan berpikir kreatif calon guru matematika dalam mengembangkan bahan ajar matematika.

\section{Rumusan Masalah}

Berdasarkan latar belakang yang telah diuraikan, rumusan masalah dalam penelitian ini adalah: Apakah penerapan project based learning berpengaruh terhadap kemampuan berpikir kreatif calon guru matematika dalam 
mengembangkan bahan ajar matematika?

\section{Tujuan Penelitian}

Penelitian ini bertujuan untuk menelaah pengaruh penerapan project based learning terhadap kemampuan berpikir kreatif calon guru matematika dalam mengembangkan bahan ajar matematika.

\section{Hipotesis Penelitian}

Dalam penelitian ini, penulis mengajukan hipotesis sebagai berikut: penerapan project based learning berpengaruh secara signifikan terhadap kemampuan berpikir kreatif calon guru matematika dalam mengembangkan bahan ajar matematika.

\section{KAJIAN PUSTAKA}

\section{Project Based Learning}

Project based learning
merupakan pembelajaran yang memberikan kebebasan kepada peserta didik untuk merencanakan aktivitas belajar, melaksanakan proyek secara kolaboratif, dan pada akhirnya menghasilkan produk kerja yang dapat dipresentasikan kepada orang lain. Project Based Learning merupakan pembelajaran untuk mengembangkan proses berpikir tingkat tinggi. Menurut Bédard dalam Chiang and Lee (2016) menyebutkan bahwa project based learning mampu mengembangkan kemampuan berpikir peserta didik, mengembangkan kreativitas peserta, mendorong siswa untuk melakukan kerjasama dalam sebuah tim. Project based learning mampu menciptakan lingkungan pembelajaran yang berpusat pada peserta didik dengan berkolaboratif.

Kriteria project based learning menurut Thomas (2000) ada lima yaitu keterpusatan (centrality), berfokus pada pertanyaan atau masalah, investigasi konstruktif atau desain, otonomi mahasiswa, dan realisme.

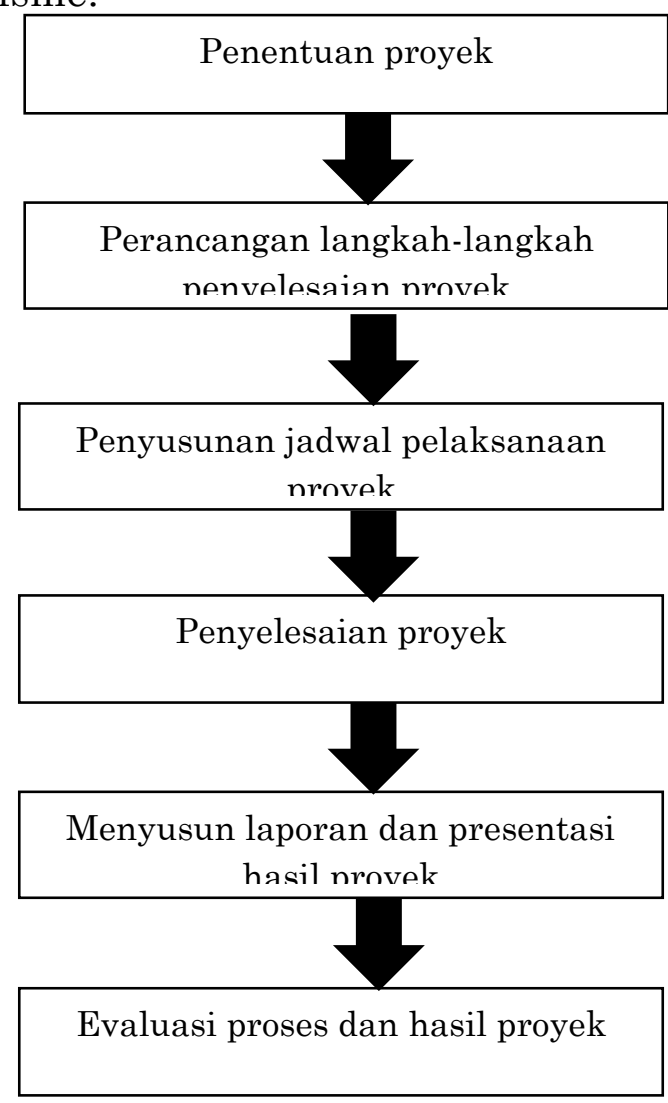

\section{Gambar 1. Langka-langkah Project Based Learning}

Langkah-langkah project based learning menurut The George Lucas Educational Foundation (2005), yaitu:

1. Start With the Essential Questio

Pembelajaran dimulai dengan pertanyaan esensial, yaitu pertanyaan yang dapat memberi penugasan peserta didik dalam melakukan suatu aktivitas.

2. Design a Plan for the Project Perencanaan dilakukan secara kolaboratif antara pendidik dan peserta didik. 
3. Create a Schedule

Pendidik dan peserta didik secara kolaboratif menyusun jadwal aktivitas dalam menyelesaikan proyek.

4. Monitor the Students and the Progress of the Project

Pengajar bertanggungjawab untuk melakukan monitor terhadap aktivitas peserta didik selama menyelesaikan proyek.

5. Assess the Outcome

Penilaian dilakukan untuk membantu pendidik dalam mengukur ketercapaian standar, berperan dalam mengevaluasi kemajuan masing-masing peserta didik, memberi umpan balik tentang tingkat pemahaman yang sudah dicapai peserta didik.

6. Evaluate the Experience Pada akhir proses pembelajaran, pengajar dan peserta didik melakukan refleksi terhadap aktivitas dan hasil proyek yang sudah dijalankan. Proses refleksi dilakukan baik secara individu maupun kelompok.

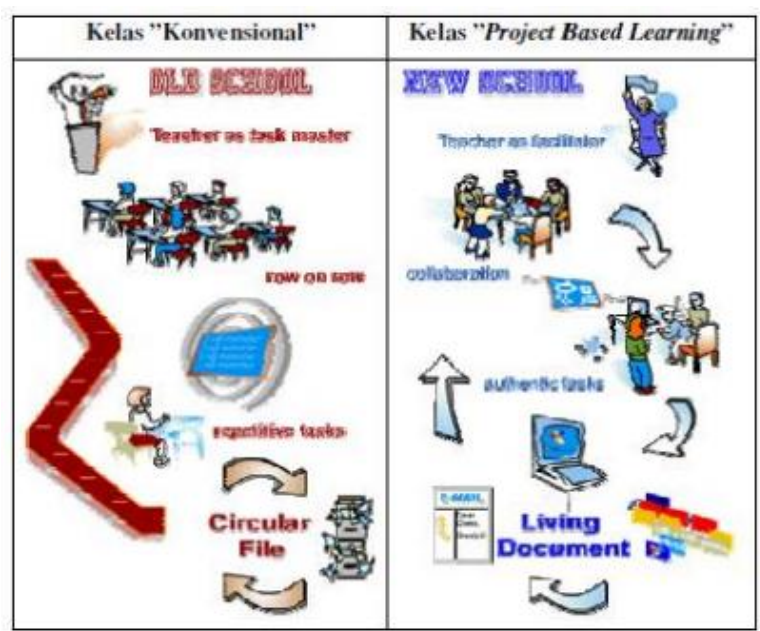

Gambar 2. Perbedaan Kelas Konvensional dengan Kelas Project Based Learning

(Sumber: Global SchoolNet, 2000)
Perbedaan proses pembelajaran antara kelas konvensional dengan kelas project based learning digambarkan dalam gambar berikut.

Suzie dan Jane (2007) menyatakan bahwa "Project Based Learning is strategy certain to turn traditional classroom upside down". Pembelajaran berbasis proyek adalah suatu strategi untuk mengubah kelas tradisional.

Abidin (2014: 172) menjelaskan bahwa tahapan project based learning adalah sebagai berikut:

1. Praproyek

Tahapan ini merupakan kegiatan yang dilakukan guru diluar jam pelajaran. Pada tahap ini guru merancang deskripsi proyek, menentukan batu pijakan proyek, menyiapkan media dan berbagai sumber belajar, dan menyiapkan kondisi pembelajaran.

2. Fase 1: Mengidentifikasi Masalah.

Pada tahap ini siswa melakukan pengamatan terhadap obyek tertentu. Berdasarkan pengamatannya tersebut siswa mengidentifikasi masalah dan membuat rumusan masalah dalam bentuk pertanyaan.

3. Fase 2: Membuat Desain dan Jadwal Pelaksanaan Proyek.

Pada tahap ini siswa secara kolaboratif baik dengan anggota

kelompok ataupun dengan guru mulai merancang proyek yang akan mereka buat, menentukan penjadwalan pekerjaan proyek, dan melakukan aktivitas persiapan lainnya.

4. Fase 3: Melaksanakan Penelitian. 
Pada tahap ini siswa melakukan kegiatan penelitian awal sebagai model dasar bagi produk yang akan dikembangkan. Berdasarkan kegiatan penelitian tersebut siswa mengumpulkan data dan selanjutnya menganalisis data tersebut dengan teknik analisis data yang relevan dengan penelitian yang dilakukan.

5. Fase 4: Menyusun Draf Produk. Pada tahap ini siswa mulai membuat produk awal sebagai rencana dan hasil penelitian yang dilakukannya.

6. Fase 5: Mengukur, Menilai, dan Memperbaiki Produk.

Pada tahap ini siswa melihat kembali produk awal yang dibuat,

mencari kelemahan, dan memperbaiki produk tersebut. Dalam praktiknya, kegiatan mengukur dan menilai produk dapat dilakukan dengan meminta pendapat atau kritik dari anggota kelompok lain ataupun dari guru.

7. Fase 6: Finalisasi dan Publikasi Produk.

Pada tahap ini siswa melakukan finalisasi produk. Setelah diyakini sesuai dengan harapan, produk dipublikasikan.

8. Pascaproyek.

Pada tahap ini guru menilai, memberikan penguatan, masukan, dan saran perbaikan atas produk yang telah dihasilkan siswa.

Kelebihan project based learning menurut Kemendikbud (dalam Abidin, 2014: 170) yaitu:

1. Meningkatkan motivasi belajar siswa untuk belajar, mendorong kemampuan mereka untuk melakukan pekerjaan penting, dan mereka perlu dihargai.

2. Meningkatkan kemampuan pemecahan masalah.

3. Membuat siswa menjadi lebih aktif dan berhasil memecahkan masalah-masalah yang kompleks.

4. Meningkatkan kolaborasi.

5. Mendorong siswa untuk mengembangkan dan mempraktikan keterampilan berkomunikasi.

6. Meningkatkan keterampilan siswa dalam mengelola sumber.

7. Memberikan pengalaman kepada siswa dalam pembelajaran dan dan praktik dalam mengorganisasi proyek, membuat alokasi waktu dan sumber-sumber lain seperti perlengkapan untuk menyelesaikan tugas.

8. Menyediakan pengalaman belajar yang melibatkan siswa secara kompleks dan dirancang untuk berkembang sesuai dunia nyata.

9. Melibatkan para siswa untuk mengambil informasi dan menunjukan pengetahuan yang dimiliki, kemudian diimplementasikan dengan dunia nyata.

10. Membuat suasana belajar menjadi menyenangkan, sehingga siswa maupun pendidik menikmati proses pembelajaran.

Kekurangan project based learning menurut Abidin (2014: 171) yaitu:

1. Memerlukan banyak waktu dan biaya.

2. Memerlukan banyak media dan sumber belajar. 
3. Memerlukan guru dan siswa yang sama-sama siap belajar dan berkembang.

4. Ada kekhawatiran siswa hanya akan menguasai satu topik tertentu yang di kerjakannya.

\section{Kemampuan Berpikir Kreatif}

Sardiman (1996: 45) menyatakan bahwa berpikir merupakan aktivitas mental untuk dapat merumuskan pengertian, mensintesis, dan menarik kesimpulan. Ngalim Purwanto (2007: 43) berpendapat bahwa berpikir adalah satu keaktifan pribadi manusia yang mengakibatkan penemuan terarah kepada suatu tujuan. Manusia berpikir untuk menemukan pemahaman/pengertian yang dikehendakinya.

Kreatif berasal dari bahasa Inggris 'create' yang artinya menciptakan, sedangkan kreatif mengandung pengertian memiliki daya cipta. Berpikir kreatif menurut LTSIN (2004) adalah "creative thinking is the process which we use when we come up with a new idea. It is the merging of ideas which have not been merged before". Berpikir kreatif adalah proses (bukan hasil) untuk menghasilkan ide baru dan ide itu merupakan gabungan dari ide-ide yang sebelumnya belum disatukan

De Bono (2007) menyatakan bahwa kemampuan siswa dalam berpikir kreatif memungkinkan siswa tersebut memperoleh banyak cara atau alternatif penyelesaian dari suatu masalah. Ide seseorang berpikir kreatif minimal mempunyai salah satu karakteristik dari: (a) ide itu belum ada sebelumnya; (b) sudah ada di tempat lain hanya saja ia tidak tahu; (c) ia menemukan proses baru untuk melakukan sesuatu; (d) ia menerapkan proses yang sudah ada pada area yang berbeda; (e) ia mengembangkan sebuah cara untuk melihat sesuatu pada perspektif yang berbeda (LTSIN: 2004).

$$
\text { Proses berpikir kreatif }
$$
menurut Wallas (Satiadarma,2003) meliputi empat tahapan yaitu:

1. Persiapan (Preparation)

Persiapan adalah tahap peletakan dasar. Dalam tahap ini dilakukan pengumpulan informasi, datadata, dan bahan-bahan untuk memecahkan masalah.

2. Inkubasi (Incubation)

Inkubasi adalah tahap dieraminya proses pemecahan masalah dalam alam pra-sadar. Tahap ini berlangsung dalam waktu tak menentu. Dalam tahap ini pula terdapat kemungkinan terjadi proses pelupaan terhadap konteksnya, dan akan teringat lagi pada saat berakhirnya tahap pengeraman dan muncul masa berikutnya.

3. Iluminasi (Illumination)

Iluminasi adalah tahap dimana munculnya aspirasi atau gagasan-gagasan untuk memecahkan masalah. Dalam tahap ini muncul bentuk cetusan spontan, ide/gagasan, pemecahan masalah, penyelesaian, cara kerja, dan jawaban baru.

4. Verifikasi (Verivication)

Verifikasi adalah tahap munculnya aktivitas evaluasi terhadap gagasan secara kritis yang mulai dicocokan dengan keadaan nyata atau kondisi kenyataan.

Indikator berpikir kreatif, menurut Guilford (Satiadarma: 2003) yaitu: 
1. Kepekaan (Problem Sensitivity) Kepekaan adalah kemampuan mendeteksi, mengenali, dan memahami serta menanggapi suatu pernyataan, situasi, atau masalah;

2. Kelancaran (Fluency), Kelancaran adalah kemampuan untuk menghasilkan banyak gagasan;

3. Keluwesan (Flexibility)

Keluwesan adalah kemampuan untuk mengemukakan bermacam-macam pemecahan atau pendekatan terhadap masalah;

4. Keaslian (Originality)

Keaslian adalah kemampuan untuk mencetuskan gagsan dengan cara-cara yang asli, tidak klise, dan jarang diberikan kebanyakan orang;

5. Elaborasi (Elaboration)

Elaborasi adalah kemampuan menambah suatu situasi atau masalah sehingga menjadi lengkap, dan merincinya secara detail, yang didalamnya terdapat berupa tabel, grafik, gambar, model dan kata-kata.

Kemampuan berpikir kreatif tidak bisa muncul dengan sendirinya melainkan butuh suatu latihan. Pendidik atau guru harus bisa melatih dan mengasah kemampuan berpikir kreatif peserta didiknya. Pendidik harus menerapkan pembelajaran yang tepat agar kemampuan berpikir kreatif peserta didik bisa munculkan dan berkembang.

Siswono (2007) mengembangkan level Tingkat berpikir kreatif menjadi lima tingkatan yaitu: tingkat 4 : sangat kreatif tingkat $3:$ kreatif, tingkat $2:$ cukup kreatif tingkat $1:$ kurang kreatif tingkat 0 : tidak kreatif

\section{Pengembangan Bahan Ajar Matematika}

Mata kuliah pengembangan bahan ajar matematika adalah mata kuliah yang mengkaji tentang berbagai bahan ajar matematika yang sedang berkembang saat ini, serta mengajarkan mahasiswa calon guru matematika untuk mampu membuat dan mengembangkan berbagai macam bahan ajar matematika untuk materi tingkat SMP dan SMA.

Output dari mata kuliah ini adalah mahasiswa calon guru matematika mampu membuat secara kreatif berbagai macam bahan ajar matematika pada tingkat SMP dan SMA. Bahan ajar yang dibuat yaitu: buku, modul, handout, LKS, brosur dan leaflet, serta multimedia interaktif. Dalam pembuatan bahan ajar sangat diperlukan kemampuan berpikir kreatif agar bisa membuat bahan ajar matematika yang menarik dan tidak membosankan.

\section{METODE PENELITIAN}

\section{Populasi dan Sampel Penelitian}

Populasi penelitian adalah seluruh mahasiswa Jurusan Tadris Matematika IAIN Syekh Nurjati Cirebon pada semester genap tahun akademik 2017/2018 dengan populasi terjangkau adalah seluruh mahasiswa jurusan Tadris Matematika IAIN Syekh Nurjati Cirebon yang mengambil mata kuliah pengembangan bahan ajar matematika pada semester genap tahun akademik 2017/2018 yakni sebanyak empat kelas (kelas A, B, C, dan D) yang berjumlah 138 orang mahasiswa. 
Dari populasi terjangkau dipilih satu kelas sampel dengan teknik cluster random sampling, yaitu mahasiswa kelas $\mathrm{C}$ sebanyak 33 orang mahasiswa.

\section{Metode dan Disain Penelitian}

Metode penelitian yang digunakan dalam penelitian ini adalah metode kuasi eksperimen dan disain penelitian ini adalah One-Shot Case Study. Penelitian ini dilakukan pada satu kelas eksprimen yang diberi treatment/perlakuan, dan selanjutnya diobservasi hasilnya.

Secara singkat, disain penelitian tersebut adalah sebagai berikut:

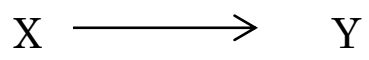

Keterangan :

$\mathrm{X}$ : perlakuan dengan menerapkan project based learning

$\rightarrow$ : pengaruh

Y : kemampuan berpikir kreatif calon guru matematika dalam mengembangkan bahan ajar matematika

\section{Variabel Penelitian}

Variabel dalam penelitian ini ada 2, yaitu: variabel bebas dan variabel terikat. Variabel bebas dalam penelitian ini adalah penerapan project based learning, sedangkan variabel terikatnya adalah kemampun berpikir kreatif calon guru matematika dalam mengembangkan bahan ajar matematika.

\section{Instrumen Penelitian}

Untuk memperoleh data dalam penelitian ini, digunakan dua macam instrumen yang terdiri dari: a) tes kemampuan berpikir kreatif dalam bentuk soal uraian untuk mengetahui kemampuan berpikir kreatif calon guru matematika yang terdiri dari sepuluh butir soal; dan b) angket untuk mengetahui respon calon guru matematika terhadap penerapan project based learning berupa 35 butir pernyataan menggunakan skala likert dengan lima pilihan jawaban, yaitu: sangat setuju (SS), setuju (S), raguragu (R), tidak setuju (TS), sangat tidak setuju (STS).

Soal tes untuk mengukur kemampuan berpikir kreatif calon guru matematika disusun berdasarkan indikator kemampuan berpikir kreatif menurut Guilford, yaitu:

1. Kepekaan (problem sensitivity)

2. Kelancaran (fluency)

3. Keluwesan (flexibility)

4. Keaslian (originality)

5. Elaborasi (elaboration)

Untuk memperoleh tes yang baik maka tes tersebut diujicobakan terlebih dahulu untuk mengetahui validitas, reliabilitas, daya pembeda dan tingkat kesukarannya. Uji coba tes ini dilakukan pada mahasiswa jurusan Tadris Matematika IAIN Syekh Nurjati Cirebon yang mengambil mata kuliah pengembangan bahan ajar matematika pada semester genap tahun akademik 2017/2018, yaitu kelas D sebanyak 32 orang mahasiswa. Dipilih kelas D karena kelas D memiliki karakteristik dan kemampuan mahasiswa yang homogen dengan karakteristik dan kemampuan mahasiwa kelas C sebagai kelas sampel.

Hasil uji coba menunjukkan bahwa seluruh butir soal valid dan dapat digunakan untuk mengukur kemampuan berpikir kreatif mahasiswa dengan reliabilitas 0.69 termasuk kategori tinggi. Taraf kesukaran soal terdiri dari: 2 soal 
mudah, 5 soal sedang dan 3 soal sukar, sedangkan untuk daya pembeda soal terdiri dari: 4 soal mempunyai daya pembeda sedang dan 6 soal mempunyai daya pembeda baik.

\section{Alur Pengolahan data}

Data yang diperoleh dari hasil tes diolah melalui tahap-tahap sebagai berikut:

1. Memberikan skor jawaban mahasiswa sesuai dengan kunci jawaban dan sistem penskoran yang digunakan.

2. Melakukan uji normalitas untuk mengetahui apakah data berasal dari populasi yang berditribusi normal atau tidak.

3. Menguji homogenitas varians data untuk mengetahui apakah data homogen atau tidak.

4. Menguji linearitas untuk mengetahui persamaan regresi yang didapat linear atau tidak.

5. Menguji koefisien regresi untuk mengetahui arah hubungan antara variabel bebas dan variabel terikat apakah positif atau negatif.

6. Menguji kebaikan model untuk mengetahui kontribusi variabel bebas terhadap variabel terikat.

7. Menguji hipotesis penelitian untuk mengetahui apakah hipotesis penelitian ditolak atau diterima.

Semua pengolahan data menggunakan bantuan software SPSS versi 22.0 dan microsoft excel.

\section{HASIL DAN PEMBAHASAN}

\section{Kemampuan Berpikir Kreatif Calon Guru Matematika}

Data kemampuan berpikir kreatif calon guru matematika diperoleh dari hasil tes berupa soal uraian yang diberikan pada kelas sampel penelitian. Kemampuan berpikir kreatif calon guru matematika setelah penerapan project based learning diukur dengan tes yang terdiri dari 10 soal uraian.

Dari hasil tes yang diberikan kepada 33 orang mahasiswa kelas $\mathrm{C}$ Jurusan Tadris Matematika IAIN Syekh Nurjati Cirebon pada semester genap tahun akademik 2017/2018, diperoleh data deskripsi statistik sebagai berikut:

Tabel 1. Deskripsi Statistik Hasil

Tes Kemampuan Berpikir Kreatif Calon Guru Matematika

\begin{tabular}{|l|l|}
\hline & $\begin{array}{l}\text { Kemampuan } \\
\text { Berpikir Kreatif }\end{array}$ \\
\hline $\mathrm{N}$ & 33 \\
\hline Min & 65 \\
\hline Max & 95 \\
\hline Sum & 2625 \\
\hline Mean & 79.55 \\
\hline Std.deviation & 9.05 \\
\hline Varians & 81.82 \\
\hline
\end{tabular}

Berdasarkan Tabel 1, jumlah mahasiswa yang mengikuti tes sebanyak 33 orang mahasiswa. Tes yang disebarkan kepada mahasiswa setelah penerapan project based learning didapat skor mean sebesar 79.55 , nilai minimum 65 dan nilai maksimum 95, serta dengan standar deviasi didapat 9.05. Nilai mean sebesar 79.55 ini dapat dikategorikan kemampuan berpikir kreatif calon guru matematika dalam mengembangkan bahan ajar matematika tergolong cukup atau sedang.

Respon Calon Guru Matematika terhadap Penerapan Project Based Learning

Untuk mengetahui respon mahasiswa sebagai calon guru 
matematika terhadap penerapan project based learning, diberikan angket yang berisi 35 pernyataan kepada 33 orang mahasiswa kelas eksperimen. Hasil dari penyebaran angket respon mahasiswa calon guru matematika terhadap penerapan project based learning, diperoleh deskripsi data respon mahasiswa calon guru matematika sebagai berikut:

Tabel 2. Deskripsi Statistik Hasil Angket Respon Mahsiswa Calon Guru Matematika

\begin{tabular}{|l|l|}
\hline & $\begin{array}{l}\text { Project Based } \\
\text { Learning }\end{array}$ \\
\hline $\mathrm{N}$ & 33 \\
\hline Min & 101 \\
\hline Max & 157 \\
\hline Sum & 4574 \\
\hline Mean & 138.61 \\
\hline Std.deviation & 21.04 \\
\hline Varians & 442.81 \\
\hline
\end{tabular}

Berdasarkan Tabel 2, angket yang disebarkan kepada 33 orang mahasiswa calon guru matematika setelah penerapan project based learning didapat skor mean sebesar 138.61, standar deviasi 21.04, nilai minimum 101 dan nilai maksimum 157. Artinya rerata skor respon mahasiswa calon guru matematika terhadap penerapan project based learning sebesar 138.61 termasuk kategori kuat/baik karena terdapat pada rentang $61 \%-80 \%$.

\section{Analisis Data}

\section{Uji Normalitas}

Uji normalitas dilakukan untuk mengetahui data berasal dari populasi yang berdistribusi normal atau tidak.
Uji statistik yang akan digunakan adalah uji Kolmogrov-Smirnov dengan mengambil taraf signifikan (a) sebesar 0.05. dengan hipotesis statistik sebagai berikut:

$\mathrm{H}_{0}$ : Data kemampuan berpikir kreatif calon guru matematika berasal dari populasi yang berdistribusi normal

$\mathrm{H}_{1}$ : Data kemampuan berpikir kreatif calon guru matematika berasal dari populasi yang tidak berdistribusi normal

Kriteria pengujiannya adalah:

$\mathrm{H}_{0}$ diterima jika nilai signifikan $>0.05$ $\mathrm{H}_{0}$ ditolak jika nilai signifikan $\leq 0.05$.

Out put menggunakan perhitungan program SPSS versi 22.0 adalah sebagai berikut:

Tabel 3. Uji Normalitas

\begin{tabular}{|l|c|c|}
\hline Kelompok & $\begin{array}{c}\text { Project } \\
\text { Based } \\
\text { Learning }\end{array}$ & $\begin{array}{c}\text { Kemampuan } \\
\text { Berpikir } \\
\text { Kreatif }\end{array}$ \\
\hline $\mathrm{N}$ & 33 & 33 \\
\hline $\begin{array}{l}\text { Kolmogorov- } \\
\text { Smirnov Z }\end{array}$ & 0.14 & 0.08 \\
\hline $\begin{array}{l}\text { Asymp. Sig. } \\
\text { (2-tailed) }\end{array}$ & 0.22 & 0.17 \\
\hline Kesimpulan & Normal & Normal \\
\hline
\end{tabular}

Dari tabel di atas diperoleh $\mathrm{p}$ value (Sig) untuk data respon mahasiswa terhadap penerapan project based learning sebesar $0.22>$ $0.025=1 / 2 \alpha$, maka hipotesis nol yang menyatakan data berasal dari populasi yang berdistribusi normal diterima,

Sedangkan p-value (Sig) untuk data kemampuan berpikir kreatif calon guru matematika sebesar $0.17>$ $0.025=1 / 2 \alpha$, maka hipotesis nol yang menyatakan data berasal dari populasi yang berdistribusi normal diterima, Jadi, semua kelompok data berasal dari populasi yang berdistribusi normal pada taraf signifikansi $\alpha=0.05$. 


\section{Uji Homogenitas}

Uji homogenitas dilakukan untuk mengetahui varians data homogen atau tidak. Uji statistik yang akan digunakan adalah uji Levene dengan mengambil taraf signifikan (a) sebesar 0.05. dengan hipotesis statistik sebagai berikut:

$\mathrm{H}_{0}$ : Kedua data memiliki varians yang homogen

$\mathrm{H}_{1}$ : Kedua data memiliki varians yang tidak homogen

Kriteria pengujiannya adalah:

$\mathrm{H}_{0}$ diterima jika nilai signifikan $>0.05$ $\mathrm{H}_{0}$ ditolak jika nilai signifikan $\leq 0.05$.

Out put menggunakan perhitungan program SPSS versi 22.0 adalah sebagai berikut:

Tabel 4. Uji Homogenitas

\begin{tabular}{|c|c|c|c|}
\hline $\begin{array}{c}\text { Levene } \\
\text { Statistic }\end{array}$ & df1 & df2 & Sig. \\
\hline 2.83 & 3 & 30 & 0.17 \\
\hline
\end{tabular}

Berdasarkan Tabel 4, dapat diketahui bahwa hasil uji homogenitas mempunyai nilai Signifikansi 0.17 berarti berada di atas 0.05 maka $\mathrm{H}_{0}$ diterima. Sehingga dapat disimpulkan bahwa kedua data tersebut homogen.

\section{Uji Linieritas}

Kelinearan regresi digunakan untuk mengetahui apakah regresi yang digunakan adalah linier atau non linier. Kelinieran regresi diperoleh dengan menggunakan bantuan program SPSS versi 22.0.

Data yang diperoleh adalah sebagai berikut:

Tabel 5. Uji Linearitas

\begin{tabular}{|l|l|l|l|}
\hline \multicolumn{2}{|l|}{} & F & Sig. \\
\hline Kreatif & & 9.42 & 0.00 \\
\hline
\end{tabular}

\begin{tabular}{|l|l|l|l|l|}
\hline Project & Betwee & Combine & 87.3 & 0.00 \\
& $\mathrm{n}$ & $\mathrm{d}$ & 1 & \\
& Groups & Linearity & & \\
\hline
\end{tabular}

Dapat diketahui bahwa nilai signifikan pada Linearity sebesar 0.00 . Karena nilai signifikansi kurang dari 0.05 maka hubungannya linear.

\section{Uji Koefisien Regresi}

Berdasarkan hasil perhitungan dengan menggunakan program SPSS versi 22.0 diperoleh data sebagai berikut:

\section{Tabel 6. Uji Koefisien Regresi}

\begin{tabular}{|l|l|c|c|c|c|}
\hline \multicolumn{2}{|l|}{$\begin{array}{l}\text { Persamaan } \\
\text { Regresi }\end{array}$} & \multicolumn{2}{|c|}{$\begin{array}{c}\text { Unstandardize } \\
\text { d Coefficients }\end{array}$} & \multirow{2}{*}{$\mathrm{t}$} & \multirow{2}{*}{ Sig. } \\
\cline { 2 - 4 } & $\mathrm{B}$ & $\begin{array}{c}\text { Std. } \\
\text { Error }\end{array}$ & & \\
\hline \multirow{2}{|l|}{1} & $\begin{array}{l}\text { Constan } \\
\mathrm{t}\end{array}$ & -1.32 & 17.43 & -1.32 & 0.12 \\
\cline { 2 - 5 } & Project & 1.03 & 0.17 & 3.44 & 0.00 \\
\hline
\end{tabular}

Model persamaan regresi linier sederhana adalah $=a+b X$, dimana $X$ adalah variabel bebas, $\mathrm{Y}$ adalah variabel terikat, a adalah penduga bagi intersep ( $\alpha$ ), b adalah penduga bagi koefisien regresi (B) dan $a, B$ adalah parameter yang nilainya tidak diketahui sehingga diduga dengan menggunakan statistik sampel.

Berdasarkan tabel di atas:

nilai $\mathrm{a}=-1.32$

nilai $b=1.03$.

Dengan demikian persamaan regresinya adalah $\mathrm{Y}=-1.32+1.03 \mathrm{X}$.

\section{Uji Koefisien Determinasi}

Kebaikan model atau uji koefisien determinasi digunakan untuk mengetahui seberapa besar prosentase pengaruh penerapan project based learning terhadap kemampuan berpikir kreatif calon guru matematika dalam 
mengembangkan bahan ajar matematika. Dengan menggunakan bantuan program SPSS versi 22.0 koefisien determinasi disajikan dalam output sebagai berikut:

Tabel 7. Uji Koefisien Determinasi

\begin{tabular}{|c|l|l|c|l|}
\hline Model & $\mathrm{R}$ & $\begin{array}{l}\mathrm{R} \\
\text { square }\end{array}$ & $\begin{array}{l}\text { Adjuste } \\
\mathrm{d} \quad \mathrm{R} \\
\text { square }\end{array}$ & $\begin{array}{l}\text { Std. } \\
\text { Error of } \\
\text { the } \\
\text { Estimate }\end{array}$ \\
\hline 1 & 0.63 & 0.53 & 0.56 & 4.36 \\
\hline
\end{tabular}

Output SPSS versi 22.0 di atas mempunyai nilai koefisien determinasi (R Square) sebesar 0.53. Artinya bahwa 53\% variabel kemampuan berpikir kreatif (Y) dipengaruhi oleh variabel $\mathrm{X}$ (penerapan project based learning).

\section{Uji Hipotesis}

Uji hipotesis dilakukan untuk mengetahui ada tidaknya pengaruh dari penerapan project based learning terhadap kemampuan berpikir kreatif calon guru matematika dalam mengembangkan bahan ajar matematika, maka selanjutnya dapat dilakukan uji hipotesis dengan menggunakan uji statistik uji $t$, dengan ketentuan hipotesis sebagai berikut :

$\mathrm{H}_{0}$ : Penerapan project based learning tidak berpengaruh secara signifikan terhadap kemampuan berpikir kreatif calon guru matematika dalam mengembangkan bahan ajar matematika.

$\mathrm{H}_{1}$ : Penerapan project based learning berpengaruh secara signifikan terhadap kemampuan berpikir kreatif calon guru matematika dalam mengembangkan bahan ajar matematika.
$\mathrm{H}_{0}$ diterima jika nilai signifikan $\geq 0,05$ $\mathrm{H}_{0}$ ditolak jika nilai signifikan $<0,05$.

Dari hasil perhitungan diperoleh pada Tabel 6 diketahui bahwa nilai signifikansi (Sig) sebesar 0,00 $<0,05$ maka hipotesis nol ditolak. Sehingga dapat disimpulkan bahwa penerapan project based learning berpengaruh secara signifikan terhadap kemampuan berpikir kreatif calon guru matematika dalam mengembangkan bahan ajar matematika.

Adapun besar pengaruh penerapan project based learning terhadap kemampuan berpikir kreatif calon guru matematika dalam mengembangkan bahan ajar matematika adalah sebesar 53\%.

\section{KESIMPULAN DAN SARAN}

\section{Kesimpulan}

Berdasarkan hasil penelitian dan pembahasan mengenai pengaruh penerapan project based learning terhadap kemampuan berpikir kreatif calon guru matematika dalam mengembangkan bahan ajar matematika diperoleh kesimpulan bahwa: penerapan project based learning berpengaruh secara signifikan terhadap kemampuan berpikir kreatif calon guru matematika dalam mengembangkan bahan ajar matematika.

Penerapan project based learning memberikan pengaruh sebesar 53\% terhadap kemampuan berpikir kreatif calon guru matematika dalam mengembangkan bahan ajar matematika.

\section{Saran}

Kriteria pengujiannya adalah: 
Berdasarkan kesimpulan di atas, maka penulis mengemukakan beberapa saran sebagai berikut:

1. Bagi para pendidik, project based learning dapat dijadikan sebagai salah satu alternatif model pembelajaran untuk diimplementasikan dalam pengembangan pembelajaran di kelas. Namun harus dipertimbangkan waktu pelaksanan yang cukup, dan pemberian tugas yang tepat agar kegiatan pembelajaran bisa berjalan kondusif dan optimal.

2. Bagi peneliti berikutnya agar:

- Menelaah kelemahan project based learning agar pembelajaran ini bisa berjalan lebih optimal.

- Menelaah apakah penerapan langkah-langkah project based learning dilakukan dengan sesuai.

- Menerapkan project based learning pada matakuliah yang lain.

- Mencari berbagai alternatif pembelajaran yang lain untuk meningkatkan kemampuan berpikir kreatif calon guru matematika dalam mengembangkan bahan ajar matematika.

\section{DAFTAR PUSTAKA}

Abidin, Y. (2014). Desain Sistem Pembelajaran dalam Konteks Kurikulum 2013. Bandung: Refika Aditama.

Amir, M Taufiq. (2012). Inovasi Pendidikan melalui Problem Based Learning. Jakarta. Prenada Media Group.

A. M, Sardiman. (1996). Interaksi dan Motivasi Belajar Mengajar, Jakarta: PT. Raja Grafindo Persada.
Boss, Suzie.,\& Krauss, Jane. (2007). Reinventing Project Based Learning: Your Field Guide To Real World Projects In The Digital Age. International Society for Technology In Education.

Chiang dan Lee. (2016). The Effect Of Project-Based Learning On Learning Motivation And Problem-Solving Ability Of Vocational High School Students. International Journal of Information and Education Technology.6(9)

De Bono, Edward. 2007. Revolusi Berpikir. Bandung: Kaifa.

Fisher, R. (1995). Teaching Children to Think. London: Stanley Thornes Ltd.

Fraenkel, J. R. dan Wallen, N. E. (1993). How to Design and Evaluate Research in Education. Singapore: Mc. Graw-Hill Book Co-Singapore.

Global SchoolNet. (2000). Introduction to Networked Project-Based Learning. Tersedia [Online]: http://www.gsn.org/web/pbl/what is.html (Diakses tanggal 12 Agustus 2016).

Haris, R. (1995). Introduction to Creative Thinking. [online]. Tersedia: http://www.virtualsal t.com/itdt.htm.

Lee, Jean S.dkk. (2014). Taking a Leap of Faith: Redefining Teaching and Learning in Higher Education through Project Based Learning. Interdiciplinary 
Journal of Problem Based Learning, Vol.8, No. 2, p:8-17

LTSIN (2004). Learning teaching. Scotland: Learning and Teaching Scotland.

Munandar, U. (2004). Pengembangan Kreativitas Anak Berbakat. Jakarta: Rineka Cipta.

NCTM. (2000). Principles and Standards for School Mathematics. USA: NCTM.

Ngalim Purwanto. (2007). Psikologi Pendidikan. Bandung: PT Remaja Rosdakarya.

P. Satiadarma, dkk. (2003). Mendidik Kecerdasan, Pedoman Orang Tua dan dalam Mendidik Anak Cerdas. Jakarta: Pustaka Populer Obor.

Ruseffendi, E.T. (1984). Pengajar Matematika Modern untuk Orang Tua, Murid, dan SPG. Bandung: Tarsito.

Ruseffendi, E.T. (1991). Pengantar kepada Membantu Guru Mengembangkan

Kompetensinya dalam

Pengajaran Matematika untuk Meningkatkan CBSA. Bandung: Tarsito.

Sandjaja, B dan Albertus, H. (2006). Panduan Penelitian. Jakarta: Prestasi Pustaka.

Sofyan, H. (2006). Implementasi Project Based Learning pada Bidang
Kejuruan. Cakrawala Pendidikan. Yogyakarta: LPM UNY.

Sumarmo, U. (2005). Pembelajaran Matematika untuk Mendukung Pelaksanaan Kurikulum Tahun 2002 Sekolah Menengah. Makalah Seminar di FPMIPA Universitas Negeri Gorontalo. Tidak Diterbitkan.

Sumarmo, U. \& Hendriana, H. (2014). Penilaian Pembelajaran Matematika. Bandung: Refika Aditama.

The George Lucas Educational Foundation. (2005). Instructional Module Project Based Learning. [Online]. Tersedia:

http//www.edutopia.org/module s/PBL/whatpbl.php. [7 juni 2010]

Thomas, J. W. (2000). A Review of Research on Project-Based Learning. California: The AutoDesk Foundation. Available on: http://www.autodesk.com/found ation.

Yuli Eko Siswono, Tatag. 2007. Penjenjangan Kemampuan Berpikir Kreatif dan Identifikasi Berpikir Kreatif Siswa dalam Memecahkan dan Mengajukan Masalah Matematika. Disertasi. Tidak dipublikasikan. (Surabaya: UNESA Pascasarjana Program Studi Pendidikan Matematika 